\title{
Mensagem do Presidente da ABPol
}

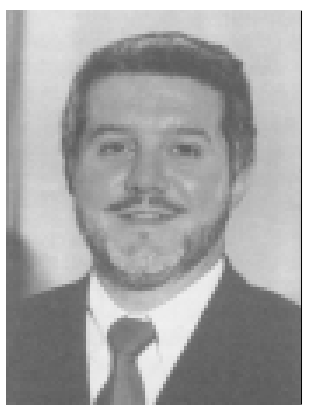

"O complexo e difícil ano de 2002 se encerra nos próximos dias com surpreendente sentimento de confiança. Nossa moeda se desvalorizou dramaticamente ao longo do ano, os juros estiveram sempre em elevação, a inflação ameaçou um retorno, os salários foram comprimidos, as linhas internacionais de crédito ao Brasil minguaram e as eleições resultaram em vitória da oposição... o país, entretanto, em nenhum momento se deixou abater e tem dado demonstrações cívicas de esperança e otimismo para 2003. A ABPol também! Em um ano de recursos escassos, receitas limitadas, custos ascendentes e imensos desafios conjunturais, a ABPol teve competência para cumprir praticamente todas as metas estabelecidas para o ano de $2002 \ldots$ os cursos em parceria com o NRPP-UFSCar/SPE, os treinamentos "in company" e as reuniões das comissões técnicas bateram recorde de público; a ABPol marcou presença em todos os congressos, feiras e eventos significativos da área de Polímeros no Brasil em 2002, várias vezes dividindo o "stand" com outras associações e instituições representativas do segmento; a Regional Leste da ABPol - com o suporte do IMA/UFRJ - promoveu o IV Encontro de Polímeros no Rio de Janeiro com sucesso; o Seminário de Polímeros do Futuro organizado pela ABPol em São Paulo foi coroado de êxito; as comissões organizadoras dos $7^{\circ}$ CBPol (2003), PPS 2004 e MACRO 2006 cumpriram todas as atividades preparatórias para a realização desses eventos; as 4 edições da Revista em 2002 mostraram constante evolução tanto em quantidade como na qualidade dos artigos e trabalhos publicados e, finalmente, mas não por último, realizamos as melhorias estruturais, funcionais e no sistema de informática da sede da ABPol em São Carlos para adequá-la à demanda de serviços projetada para os próximos 5 anos. $\mathrm{O}$ bom desempenho em 2002 ratifica nossa crença de que faremos ainda melhor em 2003. O suporte dos associados, patrocinadores, entidades de classe, membros das várias comissões e comitês, entidades de fomento, diretores, conselheiros, funcionários e amigos da $\mathrm{ABPol}$ foi o fator essencial que permitiu encerrarmos o ano com o bom sentimento de dever cumprido. Sinceros agradecimentos aos que colaboraram com a ABPol em 2002 e votos de Boas Festas e um 2003 muito positivo para todos."

Domingos Jafelice

\section{EDITORIAL}

Polímeros - Ciência e Tecnologia” termina o ano de 2002 com mais uma edição contendo 12 trabalhos científicos. Neste ano de 2002 foram publicados 41 trabalhos, representando um aumento de mais de $40 \%$ em relação ao ano de 2001. Além de trabalhos encaminhados diretamente pelos autores, neste ano recebemos também trabalhos pré-selecionados pelo Comitê Organizador do $6^{\circ}$ Congresso Brasileiro de Polímeros - IX International Macromolecular Colloquium. O maior número de trabalhos publicados foi acompanhado pela redução no tempo de análise e aceitação dos trabalhos. Esperamos continuar contando com a colaboração da comunidade de pesquisadores que atuam na área de Polímeros para manter o número e a qualidade dos trabalhos publicados.

Neste número são publicados artigos envolvendo compósitos, síntese, caracterização, processamento, reologia e biodegradação de polímeros e sistemas poliméricos. A seção editorial apresenta ainda 05 palestras apresentadas no Seminário "Polímeros do futuro: Tendências e Oportunidades".

Comitê Editorial 